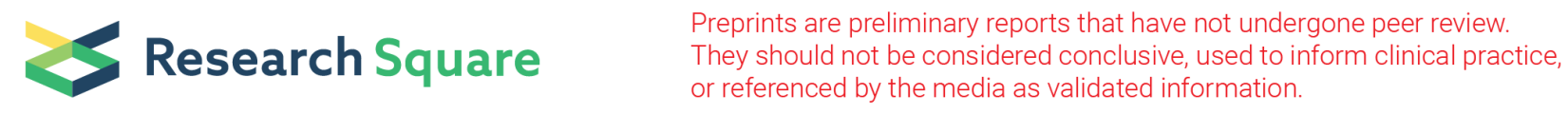

\title{
Clinical Outcome of Renin-Angiotensin-Aldosterone System Blockers in Treatment of Hypertensive Patients with COVID-19: A Systematic Review and Meta-Analysis
}

Andrea Laurentius ( $\sim$ laurentiusandrea@gmail.com )

University of Indonesia https://orcid.org/0000-0003-4340-2758

Brian Mendel

University of Indonesia

Radityo Prakoso, M.D.

National Cardiovascular Center Harapan Kita

\section{Systematic Review}

Keywords: Angiotensin Converting Enzyme Inhibitors, Angiotensin Receptor Blockers, COVID-19, Hypertension, Outcome

Posted Date: September 2nd, 2020

DOI: https://doi.org/10.21203/rs.3.rs-69847/v1

License: (c) (1) This work is licensed under a Creative Commons Attribution 4.0 International License. Read Full License 


\section{Abstract}

Background: Novel coronavirus disease 2019 has been stated as global disease pandemic due to its rapid spread worldwide. Up to $30 \%$ of Coronavirus Disease 2019 patients with hypertension are more susceptible to death. Angiotensin converting enzyme inhibitors and angiotensin receptor blockers has been used as primary line of medication for hypertension; nonetheless, conflicting data arises as numerous studies showed contradictory results.

Methods: Aiming to show clinical outcome of renin-angiotensin-aldosterone system blockers in hospital treatment of hypertensive patients with Coronavirus Disease 2019, systematically searched literatures through eight databases were intensively appraised using Strengthening the Reporting of Observational Studies in Epidemiology checklists for cohort studies.

Results: Six encompassed studies in this meta-review showed in-hospital hypertensive Coronavirus Disease 2019 patients receiving antihypertensive drugs were associated to overall risk reduction of all-cause mortalities (hazard ratio $=0.54$, confidence interval $95 \%=0.33-0.86$ ).

Conclusion: Therefore, the results support recommendation by American Heart Association not to discontinue antihypertension regimens in Coronavirus Disease 2019 patients with hypertension. Further researches are required as that majority of the studies are originated from Asian countries along with comprehensive standardization of baseline characteristics.

\section{Background}

Since March 2020, COVID-19 (novel coronavirus disease) has been declared as a global pandemic by WHO (World Health Organization), leading death toll up to 3.4 million people worldwide. Due to its envelope properties, severe acute respiratory syndrome type 2 coronavirus (SARS-CoV-2) could tolerate a wide range of environmental challenges, becoming one of the most infectious agents following HIV (human immunodeficiency virus) and influenza virus. Correspondingly, rapid spread through droplets and fomites by asymptomatic carriers are responsible for its towering transmission rate. Majority of the infected patients were diagnosed after discovering pneumonia as its clinical findings during hospitalization, including $15 \%$ with severe comorbidities. ${ }^{1}$

Preexisting hypertension represented $30 \%$ of comorbidities in COVID-19 patients, who appeared to be more susceptible to death ${ }^{2}$ Angiotensin converting enzyme inhibitor (ACEi) and angiotensin receptor blockers (ARBs) are primary line of medications for management of high blood pressure through inhibitory effect towards renin-angiotensin-aldosterone system (RAAS). ${ }^{3}$ Furthermore, SARS-CoV-2 has been known to infect alveolar epithelia through initial membrane activation of angiotensin converting enzyme 2 (ACE2). Activation of the protein facilitates internalization of viral genetic materials, thereby hijacking its host to self-replicate the viruses. ${ }^{4,5}$ Researches suggested that treatment of hypertension with either ACEi or ARBs enhances the expression of ACE2, which confer predisposition to more severe inflammatory reaction during COVID-19 infection. ${ }^{6}$ On the other hand, other reviews stated that both ACEi and ARBs serve protective role against SARS-CoV-2 infection by competitive binding to ACE2 protein. ${ }^{7}$ Because of inadequate clinical data supporting actual effects of ACEi/ARBs towards prognosis of hypertensive patients infected with COVID-19, optimal strategy for antihypertensive treatments in those patients remains to be elucidated. Controversies on novel uses of RAAS inhibitors have been raised. Therefore, the objective of this systematic review and meta-analysis were to exhaustively determine the linkage between in-hospital usage of ACEi/ARBs and all-cause mortality outcomes among COVID-19 patients with preexisting hypertension.

\section{KEYPOINTS}

Among hospitalized hypertensive patients infected with COVID-19, do angiotensin converting enzyme inhibitors (ACEi) or angiotensin receptor blockers (ARBs) improve all-cause mortality outcomes?

\section{Methods}

\section{Search Strategy}

As this article was subsequently categorized as a systematic review of cohort studies, the search was thoroughly conducted on May 2020 via accessible eight medical journal databases, including PubMed, Cochrane, ProQuest, Scopus, EBSCOhost MEDLINE, Google Scholar, ScienceDirect, and Springer. To obtain systematically objective results, two authors performed searching onto different databases using terminology listed on table 1, including their hit results. Presearching protocol of each database was carefully studied to obtain optimal search results based on keywords and title relevancy. The utilized keywords for engine searching are 'ACE inhibitors', 'Angiotensin Receptor Blockers', 'Outcome', 'COVID-19', 'SARS-CoV-2', and 'Hypertension'. Search strategy results were summarized in the following standardized PRISMA (Preferred Reporting Items for Systematic Review and Meta-Analysis) flow diagrams figure 1. Nonetheless, three databases were not mentioned in the flow diagram as no literature was relevant.

\section{Eligibility Criteria}

All screened articles were then assessed for eligibilities, involving title and abstracts skimming, double-checking for full text availability, and final selecting based on inclusion-exclusion criteria. Studies involving adult patients who had pre-existing hypertension and diagnostically confirmed with COVID-19 infection were included in the appraisals. Assessment of inclusion criteria in the screened articles have to consider the following definitions. Pre-existing hypertension is defined as history of systolic or diastolic blood pressure of $140 \mathrm{mmHg}$ or $90 \mathrm{mmHg}$ respectively or greater and previous records of antihypertensive medications. According to American Academy of Pediatrics, patients 18 years old and older are considered as adults. ${ }^{8}$ Moreover, COVID-19 was diagnosed with reverse transcription-polymerase chain reaction (RT-PCR) confirmation of pharyngeal swab samples and meeting one or more criteria of computerized 
tomography (CT) chest manifestations based on New Coronavirus Pneumonia Prevention and Control Program and WHO interim guidance. ${ }^{9,10}$ Included studies were also either prospective or retrospective cohorts comprising of antihypertensive treatment group with ACEi/ARB and non-ACEi/ARB during followup observation in hospitals. Studies that involve hypertensive patients with undefined cardiovascular comorbidities were excluded, as well as studies older than five years old.

\section{Critical Appraisal}

The eligible studies were intensively appraised using STROBE (Strengthening the Reporting of Observational Studies in Epidemiology) statements for cohort studies. ${ }^{11}$ It comprises of 22 statements depicting completion of checklists required for each section to assess article's validity, reliability, and applicability into the analysis. The critical appraisal of each study was conducted based on unanimous consensus from all authors discussing on this systematic review. Level of completeness in each checklist was qualitatively shown in the table 2.

\section{Data Extraction}

Data extraction from each selected article included authorships, study year and design, population characteristics, population size, duration of follow-up, defined comorbidities, hypertension grading, duration of follow-up, and outcome. The primary endpoint of this review is defined as the all-cause mortality outcome of hypertensive patients with COVID-19; nevertheless, the secondary endpoints were comorbidities in hospitalized hypertensive patients due to COVID-19.

\section{Statistical Meta-Analysis}

Extracted values of primary endpoint were transposed into hazard ratio via generic inverse variance. Adjusted HR was calculated via logistic hazard ratio through computational random effect model. Estimation of $95 \%$ confidence interval $(\mathrm{Cl})$ and p-value were added to support risk evaluation of the endpoint. To optimize metadata summary from different articles, interstudy forest and funnel plot comparison was conducted via Review Manager 5.3 and Microsoft Office Excel software. Additionally, chi-square tests and Cochrane Q score were used to quantitatively examine heterogeneity between studies. Two-tailed $\mathrm{p}$ value of less than 0.05 is considered statistically significant. ${ }^{11}$ Lastly, studies with high risk bias results were excluded from meta-analysis.

\section{Results}

\section{Search Results}

A comprehensive search was done using eight different journal databases. All search terms are provided in Table 1 . Of all 500 potentially relevant articles identified through the initial search, 32 were found to be duplicate articles. Hence, the remaining 468 were screened based on titles and abstracts, and a number of 453 articles were excluded in accordance to inclusion criteria. Thus, 15 full texts of the remaining articles were further assessed for eligibility criteria. Nine articles were not included into the final selected articles in analysis due to incomplete data and written in non-English language. Description of these sequential steps in systematic studies selection is done by constructing The Preferred Reporting Items for Systematic Reviews and Meta-Analysis (PRISMA) diagram shown in Figure 1. ${ }^{12}$

Table 1. Search strategy on used available keywords. 


\begin{tabular}{|c|c|c|c|}
\hline Database & Search Terms & Hits & Selected Articles \\
\hline PubMed & $\begin{array}{c}\text { (ACEi OR ARB) AND } \\
\text { (Outcome) }\end{array}$ & 11 & 4 \\
\hline EBSCOhost MEDLINE & $\begin{array}{c}\text { AND (Hypertension) AND } \\
\text { (COVID-19 } \\
\text { OR SARS-CoV-2) }\end{array}$ & 6 & 2 \\
\hline Google Scholar & & 449 & 3 \\
\hline ScienceDirect & & 33 & 0 \\
\hline Cochrane & & 1 & 0 \\
\hline ProQuest & & 0 & 0 \\
\hline Springer & & 0 & 0 \\
\hline Scopus & & 0 & 0 \\
\hline
\end{tabular}

\section{Studies Appraisal}

Critical appraisal was extensively conducted on six observational studies via STROBE checklists. ${ }^{11}$ Based on the appraisal checklists, Zhang et al. turns out to be the most reliable, valid, and applicative studies which is characterized by fully mentioned points in all sections. Moreover, moderate risk of reliability bias due to low methodological descriptions is found in Li et al. and Meng et al. studies, followed by Mehra et al. No significant risk of validity bias based on results checklists has been found among studies. However, low to moderate risk of applicability bias is described as unclear interpretation and generalizability of the results in Meng et al. study. The complete results are qualitatively shown in the following table, shown in table 2. ${ }^{13-18}$

Table 2. Critical appraisal results of trial studies. ${ }^{11}$ 


\begin{tabular}{|c|c|c|c|c|c|c|c|}
\hline \multicolumn{2}{|c|}{ CHECKLISTS } & \multirow{2}{*}{$\frac{\text { Li et al. (2020) }}{\square}$} & \multirow{2}{*}{$\begin{array}{c}\text { Meng et al. (2020) } \\
\square\end{array}$} & \multirow{2}{*}{$\begin{array}{c}\text { Zhang et al. (2020) } \\
\square\end{array}$} & \multirow{2}{*}{$\begin{array}{c}\text { Yang et al. (2020) } \\
\end{array}$} & \multirow{2}{*}{$\begin{array}{c}\text { Lee et al. (2020) } \\
\square\end{array}$} & \multirow{2}{*}{$\begin{array}{c}\text { Mehra et al. (2020) } \\
\end{array}$} \\
\hline Title and & Abstract & & & & & & \\
\hline Introduction & Background & 口 & 口 & प & 口 & प & प \\
\hline & Objectives & 口 & 口 & प & 口 & प & प \\
\hline \multirow[t]{9}{*}{ Methods } & Study Design & प & प & प & प & प & $*$ \\
\hline & Setting & 口 & 口 & 口 & 口 & प & 口 \\
\hline & Participants & $*$ & - & 口 & 口 & 口 & - \\
\hline & Variables & 口 & प & 口 & 口 & प & प \\
\hline & Data Sources & प & प & प & प & प & प \\
\hline & Bias & - & - & प & प & प & 口 \\
\hline & Study Size & - & - & प & $*$ & - & - \\
\hline & Quantitative Variables & - & - & प & 口 & प & $*$ \\
\hline & Statistical Methods & $*$ & $*$ & प & प & प & प \\
\hline \multirow[t]{5}{*}{ Results } & Participants & प & प & प & प & प & प \\
\hline & Descriptive Data & 口 & $*$ & प & 口 & प & 口 \\
\hline & Outcome Data & प & प & प & प & प & प \\
\hline & Main Results & 口 & 口 & प & प & प & प \\
\hline & Other Analyses & 口 & 口 & 口 & $\square$ & प & प \\
\hline \multirow[t]{4}{*}{ Discussion } & Key Results & $\square$ & 口 & प & प & 0 & 0 \\
\hline & Limitations & $\square$ & - & प & प & प & प \\
\hline & Interpretation & $\square$ & $*$ & 口 & $\square$ & 口 & प \\
\hline & Generalizability & 口 & $*$ & प & प & $*$ & $*$ \\
\hline Other Information & Funding & प & प & प & प & प & प \\
\hline
\end{tabular}

Information: () complete; (*) unclear; (-) incomplete.

Study Results

\section{Comparative Data Extraction}

Based on the result evaluation from six retrospective cohorts involving more than 1,000 patients across China and other countries, majority of the studies were conducted to assess the probable outcomes of RAAS blockers within hypertensive patients infected with COVID-19. Furthermore, those studies were recently held during early outbreak of COVID-19 in mainland China. Data collection of patients' medical records from respective hospitals mostly began in January 2020; nevertheless, Yang et al. study yields the earliest time of records collection, that was on November 2019 in Wuhan. Additionally, Meng et al. defined hypertension based on its grading in patients infected with COVID-19 to observe any substantial differences in mortality outcomes. Largest sample size was seen in study done by Lee et al but not more than 42 patients as the fewest one in study done by Meng et al. The following table $\mathbf{3}$ summarizes data extractions from the selected observational studies. 
Table 3. Data Extraction of Selected Studies. ${ }^{13-18}$

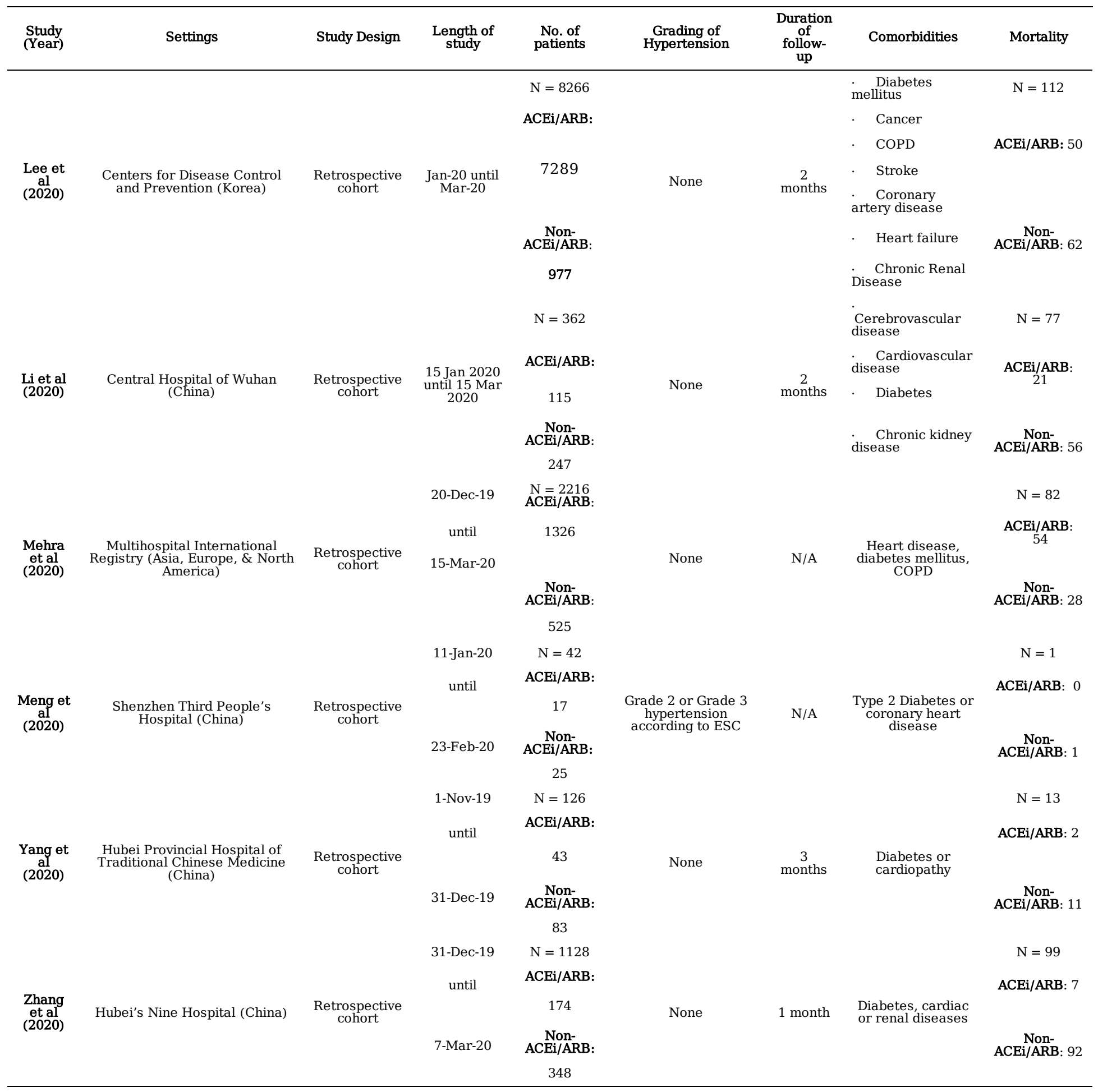

\section{Primary and Secondary Outcomes}

Patient characteristics between group of ACEi/ARB and non-ACEi/ARB represents distribution of potential confounding factors. Significant difference of mean age between groups was only found in Lee et al study as other studies exhibit similar age distribution between groups. Discrepancy of female-to-total patient ratio between groups suggests risk bias of results, for each gender possesses contrasting effects of ACEi/ARB toward cardiovascular outcome. Besides, five studies involve data source from Asian patients, except the multinational cohort study done by Mehra et al. The consistency of race belonging to every patient due to the fact that the study's coverage was limited to single country. The overall primary outcome of this review is all-cause mortality of pre-existing hypertensive patients infected with COVID-19; on the other hand, the secondary outcomes would be to evaluate comorbidities in patients that could obscure the survival value of ACEi/ARB. All defined comorbidities were generalized into five main subgroups as they represented the most frequent cause of deaths in VO, comprising of diabetes mellitus, coronary artery disease, congestive heart failure, chronic kidney disease or renal failure, and cerebrovascular disease or stroke. Study conducted by Lee et al. exhibited disparities of comorbidities between observed groups, which is statistically proven by respective p-value under 0.05. This may generate unimportant research results due to its nature of high-risk bias among populations in the groups. Mehra et al. did not specifically 
summarize the characteristics based on ACEi/ARB grouping; therefore, it would be posed as unimportant research in the overall meta-analysis. The following table 4 qualitatively summarize the data of patient characteristics in all selected studies.

Table 4. Summarized Data of Patients' Characteristics. ${ }^{13-18}$

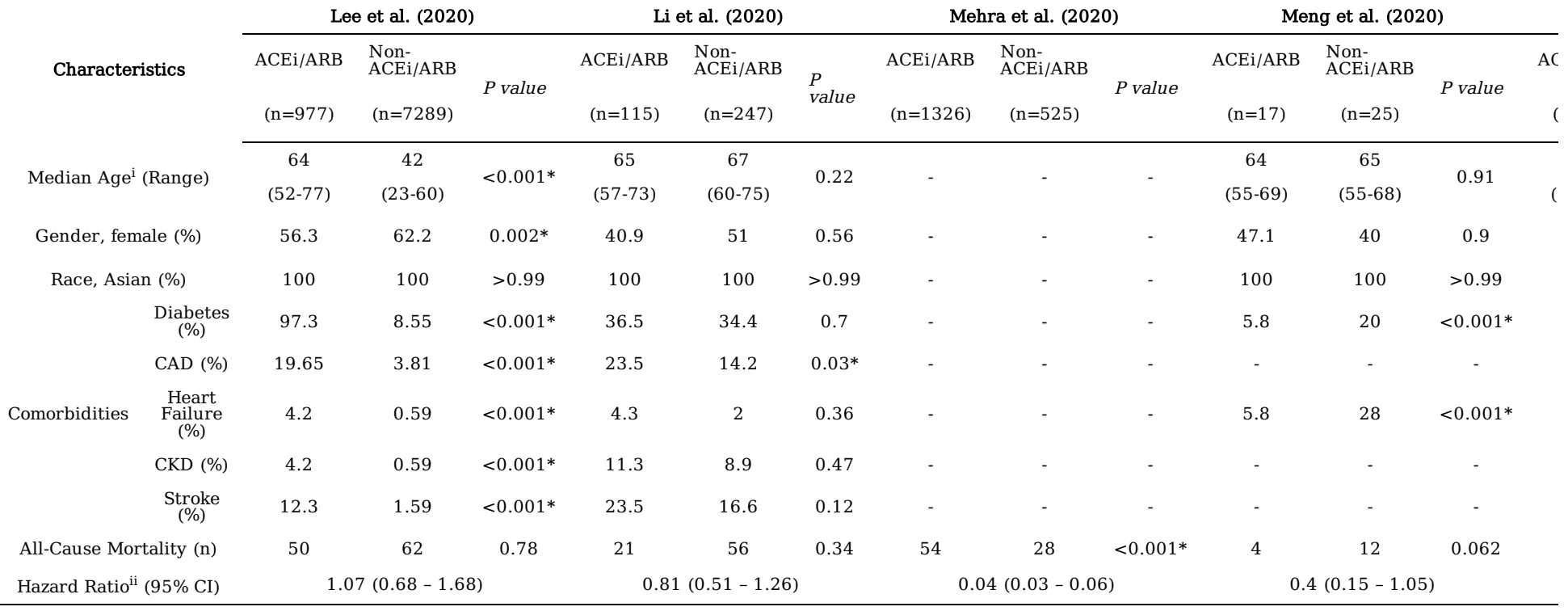

i. Age is calculated as unit of year. Asterisked p-values $\left(^{*}\right)$ indicate statistically significant data. Mean difference of age is calculated via indep via Chi-Square test.

ii. Hazard ratio $<1$ shows risk reduction of all-cause mortality in the ACEi/ARB treated group.

\section{Meta-Analysis}

Few detailed studies in the literature concerns the usage of ACEi/ARB that could exacerbate severity of COVID-19 in hypertensive patients. This is reflected by the overall result suggesting reduction of all-cause mortality by ACEi/ARB hospital treatment $(\mathrm{HR}=0.54,95 \% \mathrm{Cl}=0.33-0.86)$. Two studies (Lee et al. and Mehra et al.) were not included in the analysis as their metadata produce significant heterogeneity. Model of random effect was used in the meta-analysis, yielding proportional and conservative quantification of each study result. Heterogeneity indexes $\left(l^{2}=31 \%\right)$ and statistically insignificant Cochrane $Q$ test $(p=$ $0.23, \mathrm{Q} / \mathrm{df}=0.07$ ) denote moderately homogeneous studies results. Moreover, the $\mathrm{p}$-value of overall effects was 0.01 ( $\mathrm{z}$-score $=2.56$ ), supporting validity of the meta-analysis. Taken together, the result indicates confirmed usage of ACEi/ARB associated with reduced outcome mortality in adult COVID-19 hypertensive patients.

\section{Discussion}

Renin-Angiotensin-Aldosterone (RAAS) system has been reported to play a central role in regulating hypertension and acute lung injury. Therefore, effective therapeutic strategy targeting RAAS, such as ACEi and ARBs, through inhibition of ACE/Angll/AT1R axis is the commonest used drugs for hypertension. Data from Wuhan stated that $10.5 \%$ mortality among person with COVID-19 who also had comorbidities, consisting of diabetes (7.3\%), hypertension (6\%), respiratory disease (6.3\%), and cancer (5.6\%). While Mayo Clinic Proceedings mentioned that the most common comorbidities in 481 patients of a cohort study were $74 \%$ for hypertension, $22 \%$ for atrial fibrillation, $30 \%$ for ischemic cardiopathy, and $34 \%$ for diabetes. Hypertensive COVID- 19 patients are prone to progress into grave cases and choices should be made to determine the effect of RAAS blockers on COVID-19 patients with pre-existing hypertension. ${ }^{19-21}$

According to a special report by Vaduganathan et $\mathrm{al}^{2}{ }^{2}$ ACE2 is expressed in multiple organs, including heart, kidneys, and lung alveolar cells, which are the target of severe acute respiratory syndrome coronavirus 2 (SARS-CoV-2) regarding its function as binding sites for the virus. This fact raised concerns regarding the utilization of ACE inhibitors and ARBs which may exacerbate severity of COVID-19 patients. ACE inhibitors and ARBs possess heterogenous effects on ACE2 in animal studies, while little data exist on the pharmacokinetic effect of ACE inhibitors and ARBs on human. Many researches had conflicting data, indicating various effects on ACE2 across different molecules of ACE inhibitors and ARBs. However, no research has showed higher virulence of SARSCoV-2 in either ACEi or ARBs treated patients. ${ }^{22,23}$ These conflicting results may be due to confounding factors in the studies. In our systematic review, Mehra et $\mathrm{al}^{18}$ and Zhang et $\mathrm{al}^{15}$ are the only studies which perspiciously stated the sole comorbidity is hypertensive. However, all studies ${ }^{13-18}$ in synergism showed that mortality rates went down with the employment with ACE inhibitor or ARB in all subjects.

In response to the problems, American Heart Association (AHA) has recommended new guidelines for management of hypertension in patients visiting healthcare during COVID-19. The recommendation suggests hypertensive COVID-19 patients should not stop taking either ACEi or ARB. Controversies arose when it was brought to light that SARS-CoV-2 could bind to ACE2 receptor to acquire access into cells. Several animal studies indicate that ACEi and ARB increase expression of ACE2 and raised wide concerns that using these types of antihypertensives exacerbate susceptibility to the virus. Increased level of ACE2 on one hand may facilitate infection by COVID-19 and elevate the risk of developing severe and fatal COVID-19 manifestations. Reduced expression of 
ACE2 could trigger pulmonary edema and reduced lung function; In contrast, other studies claimed that it reduces systemic levels of angiotensin-2 which may be protective against lung damages in COVID-19 patients. ${ }^{24-26}$

Furthermore, Lancet Respiratory Medicine suggested hypertensive patients have hyperactive RAAS activation through angiotensin-2 which has been assumed to conciliate acute lung injury including lung inflammation, fibrosis and even edema during SARS-CoV-2 virus infection. Activation of ACE2 results in low quantity of angiotensin-2, and its impairment would result in excessive release of angiotensin-2. Angiotensin-2 positively adjusts the expression of cytokines through angiotensin 2 type 1 receptor (AT1R) activation. Correspondingly, study from China showed higher angiotensin-2 serum level in a group of 12 SARSCoV-2-infected patients compared to the uninfected and was synergistically associated with lung damage and viral loads. ${ }^{24-26}$ Not only related with abysmal prognosis of COVID-19 disease, hypertension was also linked to decreased amounts of ACE2 expression. Studies suggested that COVID-19 interaction with ACE2 receptor may cease residual ACE2 activity, elevating angiotensin-2 levels and several studies stated that binding of ARB to the AT1R may stabilize the AT1R-ACE2 complex and halt SARS-CoV-2-ACE2 interface. ${ }^{24-26}$ Currently, all guidelines recommend that patients with hypertension comorbidity should not discontinue ACEi or ARBs in this setting except for clinical reasons.

In view of the fact that nearly all of the studies originated from China or Asian countries, researches from non-Asian countries should also be conducted to secure more generalized and accepted utilization of ACE-inhibitor or ARB in hypertensive COVID-19 patients. Furthermore, studies were compelled to mention in lucidity regarding the scope of follow-up duration, grade of hypertension, age, gender, and the other baseline characteristics should also be standardized. Additional outcomes other than mortality could be assessed such as in hospital bedrest duration.

\section{Conclusion}

All encompassed studies showed that hypertensive patients with COVID-19 who received ACE inhibitor or ARB in hospital treatment were associated to lower risk of all-cause mortalities compared to the non-users. The results support recommendation by American Heart Association not to discontinue previous treatment of ACEi/ARBs among COVID-19 patients with hypertension. Even though studies interpretation compelled to contemplate the possibility for residual confounders, it is implausible that hospitalized ACE-inhibitor or ARB patients would be related to elevated likelihood of impermanence. Thus, further researches are required as that majority of the studies are originated from Asian countries along with comprehensive standardization of baseline characteristics.

\section{Abbreviations}

$\begin{array}{ll}\text { ACE } & \text { Angiotensin Converting Enzyme } \\ \text { ACEi } & \text { Angiotensin Converting Enzyme Inhibitors } \\ \text { AHA } & \text { American Heart Association } \\ \text { ARB } & \text { Angiotensin Receptor Blockers } \\ \text { CI } & \text { Confidence Interval } \\ \text { COVID-19 } & \text { Novel Coronavirus Disease 2019 } \\ \text { CT } & \text { Computed Tomography } \\ \text { Df } & \text { Degree of Freedom } \\ \text { HIV } & \text { Human Immunodeficiency Virus } \\ \text { HR } & \text { Hazard Ratio } \\ \text { PRISMA } & \text { Preferred Reporting Items for Systematic Review and Meta-analysis } \\ \text { RAAS } & \text { Renin-Angiotensin-Aldosterone System } \\ \text { RT-PCR } & \text { Reversed-Transcriptase Polymerase Chain Reaction } \\ \text { SARS-CoV-2 } & \text { Severe Acute Respiratory Syndrome Type 2 Coronavirus } \\ \text { STROBE } & \text { Strengthening the Reporting of Observational Studies in Epidemiology } \\ \text { WHO } & \text { World Health Organization }\end{array}$

\section{Declarations}


Authors are grateful to have had excellent work during this and other related project. The authors would especially like to thank chief of Division of Pediatric Cardiology and Congenital Heart Disease, who has provided extensive personal and professional guidance and taught the author a great deal about scientific research in cardiovascular medicine.

\section{Authorship}

All persons who meet authorship criteria are listed as authors, and all authors certify that they have participated equally in the work to take public responsibility for the content, including participation in the concept, design, analysis, writing, revision, or final approval of the manuscript. Furthermore, each author certifies that this material or similar material has not been and will not be submitted to or published in any other publication.

\section{Funding}

This research received no specific grant from any funding agency in the public, commercial, or not-for-profit sectors.

\section{Availability of Data and Materials}

All data generated or analyzed during this study are included in this published article (and its supplementary information files).

\section{Conflict of Interests}

All authors hereby declare that they have no competing interest and other potentially conflicting interests, including specific financial interests and relationships and affiliations relevant to Egyptian Heart Journal.

\section{Consent for Publication}

Not applicable. Written informed consent for publication was not necessary because no patient data has been included in the manuscript.

\section{Ethical Approval}

Not applicable. No ethical approval will be needed because data from previous published studies in which informed consent was obtained by primary investigators will be retrieved and analyzed.

\section{Human Rights}

This article does not contain any studies with human subjects performed by the any of the authors.

\section{References}

1. Guan WJ, Ni ZY, Hu Y, et al (2020) Clinical characteristics of coronavirus disease 2019 in China. N Engl J Med 382:1708-1720.

2. Huang C, Wang Y, Li X, et al (2020) Clinical features of patients infected with 2019 novel coronavirus in Wuhan, China. Lancet 395:497-506.

3. Flack JM, Adekola B (2020) Blood pressure and the new ACC/AHA hypertension guidelines. Trends Cardiovasc Med 30:160-164.

4. Hoffman M, Kleine-Weber H, Schroeder S, et al (2020) SARS-CoV-2 cell entry depends on ACE2 and TMPRSS2 and is blocked by a clinically proven protease inhibitor. Cell 181(2):271.e8-280.e8.

5. Walls AC, Park YJ, Tortorici MA, Wall A, McGuire AT, Veesler D (2020) Structure, function, and antigenicity of the SARS-CoV-2 spike glycoprotein. Cell 181(2):281.e6-292.e6

6. Fang L, Karakiulakis G, Roth M (2020) Are patients with hypertension and diabetes mellitus at increased risk for COVID-19 infection? Lancet Respir Med 8(4):e.21

7. Imai Y, Kuba K, Rao S, et al (2005) A crucial role of angiotensin converting enzyme 2 (ACE2) in SARS coronavirus-induced lung injury. Nat Med 11(8):8759.

8. Hardin A, Hackell J (2017) Age limit of pediatrics. Pediatrics 140(3):e20172151.

9. New coronavirus pneumonia prevention and control program (2020) National Health Commision of China. http://en.nhc.gov.cn. Accessed 4 May 2020.

10. Laboratory testing for 2019 novel coronavirus (2019-nCoV) in suspected human cases Interim guidance (2020) World Health Organization. https://www.who.int/publications-detail/laboratory-testing-for-2019-novel-coronavirus-in-suspected-human-cases-20200117. Accessed 4 May 2020.

11. STROBE statement: available checklists (2007) Strobe-statement.org. https://www.strobe-statement.org/index.php?id=available-checklists. Accessed 9 May 2020 .

12. PRISMA (2015) Prisma-statement.org. http://prisma-statement.org/PRISMAStatement/FlowDiagram. Accessed 9 May 2020.

13. Li J, Wang X, Chen J, Zhang H, Deng A (2020) Association of renin-angiotensin system inhibitors with severity or risk of death in patients with hypertension hospitalized for coronavirus disease 2019 (COVID-19) infection in Wuhan, China. JAMA Cardiology 5(7):825-830.

14. Meng J, Xiao G, Zhang J, He X, Ou M, Bi J, et al (2020) Renin-angiotensin system inhibitors improve the clinical outcomes of COVID-19 patients with hypertension. Emerging Microbes \& Infections 9(1):757-60.

15. Zhang P, Zhu L, Cai J, Lei F, Qin J, Xie J, et al (2020) Association of inpatient use of angiotensin converting enzyme inhibitors and angiotensin II receptor blockers with mortality among patients with hypertension hospitalized with COVID-19. Circulation Research 126:1671-1681. 
16. Yang G, Tan Z, Zhou L, Yang M, Peng L, Liu J, et al (2020) Angiotensin II receptor blockers and angiotensin-converting enzyme inhibitors usage is associated with improved inflammatory status and clinical outcomes in COVID-19 patients with hypertension. MedRxiv. doi:

10.1101/2020.03.31.20038935.

17. Lee H, Ahn J, Kang C, Won S, Park J, Kang C, et al (2020) Association of angiotensin II receptor blockers and angiotensin-converting enzyme inhibitors on COVID-19 related outcome. Research Square. doi: 10.21203/rs.3.rs-29483/v1.

18. Mehra M, Desai S, Kuy S, Henry T, Patel A (2020) Cardiovascular disease, drug therapy, and mortality in COVID-19. N Engl J Med 382:e102

19. Wu Z, McGoogan JM (2020) Characteristics of and important lessons from the coronavirus disease 2019 (COVID-19) outbreak in China: summary of a report of 72314 cases from the Chinese Center for Disease Control and Prevention. JAMA 323(13):1239-1242.

20. Vaduganathan M, Vardeny O, Michel T, et al (2020) Renin-angiotensin-aldosterone system inhibitors in patients with Covid-19. N Engl J Med 382:16531659.

21. Tignanelli CJ, Ingraham NE, Sparks MA, et al (2020) Antihypertensive drugs and risk of COVID-19? Lancet Respir Med 8(5): e30-e31.

22. Sanchis-Gomar F, Lavie CJ, Perez-Quilis C, et al (2020) Angiotensin-converting enzyme 2 and antihypertensives (angiotensin receptor blockers and angiotensin-converting enzyme inhibitors) in coronavirus disease 2019. Mayo Clinic Proc. Available via DIALOG.

https://www.mayoclinicproceedings.org/article/S0025-6196(20)30315-3/pdf. Accessed 9 May 2020.

23. What people with high blood pressure need to know about COVID-19: American Heart Association (AHA) guidance (2020) Dallas, TX: AHA.

https://newsroom.heart.org/news/what-people-with-high-blood-pressure-need-to-know-about-covid-19. Accessed 9 May 2020.

24. CDC COVID-19 Response Team (2020) Preliminary estimates of the prevalence of selected underlying health conditions among patients with coronavirus disease 2019 - United States, February 12-March 28. MMWR Morb Mortal Wkly 69:382-386.

https://www.cdc.gov/mmwr/volumes/69/wr/mm6913e2.htm. Accessed 6 May 2020

25. Liu Y, Yang Y, Zhang C, et al (2020) Clinical and biochemical indexes from 2019-nCoV infected patients linked to viral loads and lung injury. Sci China Life Sci 63:364-374.

26. Wang X, Khaidakov M, Ding Z, et al (2012) Cross-talk between inflammation and angiotensin Il: studies based on direct transfection of cardiomyocytes with AT1R and AT2R cDNA. Exp Biol Med 237 (12):1394-1401.

\section{Figures}

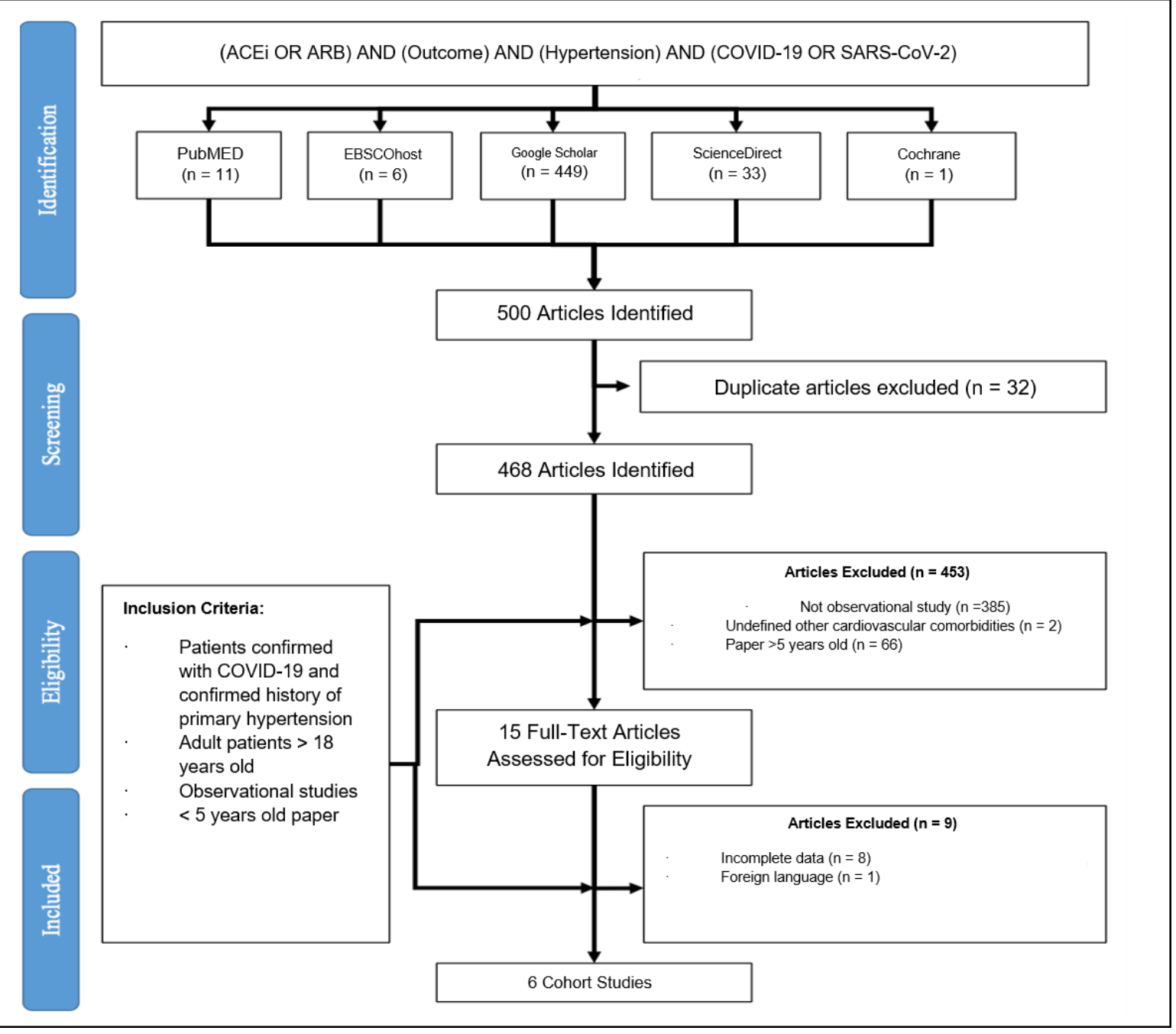

Page $10 / 11$ 
Figure 1

Schematic search strategy results in the standardized PRISMA flow diagram.

A)

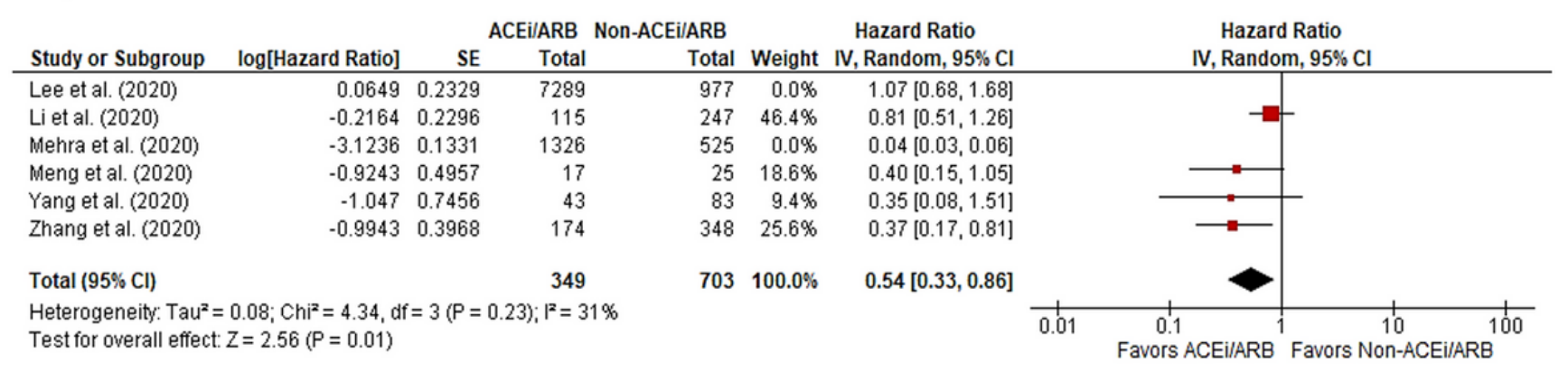

B)

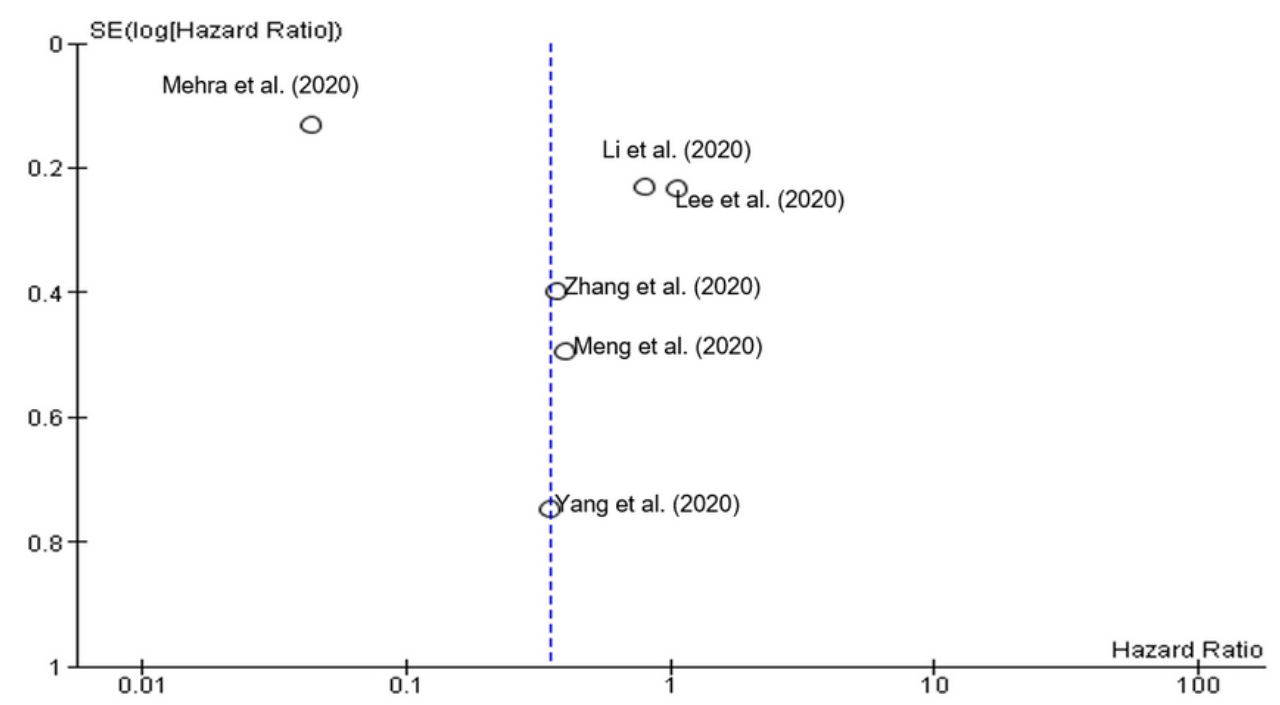

Figure 2

A) Forest-plot of hazard ratio comparison: Outcome of ACEi/ARB. B) Estimate of study publication bias scattered in funnel plot. 